\title{
The Extent to Which Open and Distance Learning Students Utilize Information and Communication Technologyin Their Assignments and Research Projects.
}

\author{
Dr. Onias Mafa \& Mr. John Mpofu. \\ Zimbabwe Open University.
}

\begin{abstract}
The study sought to interrogate the extent to which open and distance learning (ODL) students utilized information and communication technology (ICT) in writing assignments. We used a qualitative design. ODL students, programme coordinators and library assistants were purposively sampled. Data were generated through focus group discussions with programme coordinators, in-depth interviews with library assistants and questerviews that were responded to by ODL students. Major findings were that - the extent to which ODL students utilized ICT depended on age of students and programme of study and that very few ODL students made of ICT. Problems associated with the use of ICT included - ODL students' lack of ICT skills; internet connectivity challenges; the number of computers available at the university and high cost of acquiring personal computers and laptops. The study made the following recommendations - equipping ODL students with ICT skills through hands-on training; increasing the number of computers in the university's library and computer laboratories and the country's adoption of an affirmative action where registered college and university students could be allowed to buy laptops at subsidized prices.
\end{abstract}

Key terms:Open and distance learning, Students, Information and Communication Technology, Assignments and Research Projects.

\section{Introduction}

ODL students learn at a distance from the campus and their tutors. This leads one to assume that in this age of ICT, such students are bound by circumstances to make greater use of the internet in accessing information for their assignments and research projects. In addition, more and more academic journals and books can be accessed online. This being the case, the purpose of the study was to establish the extent to which ODL students utilized the university's ICT facilities in their assignments and research projects. The study was informed by the following research questions:

- To what extent do the ODL students make use of ICT in the preparation and writing of assignments and research?

- What challenges do ODL students encounter in their attempt to utilize ICT?

- How can these challenges be addressed?

\section{The concept Information and Communication Technology}

\section{Review Of Related Literature}

Rouse (2005) views ICT as an umbrella term that includes communication devices or applications encompassing radio, television, cellular phones, computers and network hardware and software, satellite systems as well as various services and applications associated with them such as video conferencing and distance learning. In ODL, ICT makes it possible to avail various support servicesto students at different phases of their learning cycle. The various phases include the admission phase (program details, fee structure, admission procedure, and registration and re-registration), the learning phase (learning schedule, programme delivery (lectures through video conferencing, webinars, audio and video programmes, multimedia presentations and case studies), evaluation phase (examination schedule, internal and external assessment, examinations, improvement, valuation, revaluation and publication of results and the certification phase (marks/grades updates, certificate printing and issuing and convocation schedule) (Murali, 2009).

Akpan (2008:8) defines ICT as:. . . a process of creation, processing, storage, retrieval and dissemination of information and data using computers and telecommunications. ICT allows electronic communication through facsimile, e-mail, voice mail, video conferencing and has led to the widespread use of networking technologies such as internet, World Wide Web, intranet and extranet, online data bases, integration of information systems and mobile communication.

Johnson (2007) in Akpan (2008) points out that ICT entails collecting, storing, processing, communicating and delivering of information related to teaching and learning processes using a combination of technologies. This study limits ICT to the use of computers and internet by ODL students. 


\section{Benefits of ICT in ODL}

The Zimbabwe Open University distance learning system, is such that students operate from various parts of the country away from the university's national and regional centres. It is difficult for a learner to visit the institution every day to get a service/support as available in a conventional system and at the same time, it is even difficult for the institution itself to provide various services to the learners at different phases of a student learning life cycle, due to limited human resource availability. At admissions, the student is supposed to register at the regional centre but if he/she is too far away registration can be done through internet. In the conventional system, students are able to interact with one another face-to-face, which is a prerequisite for more meaningful social intercourse. Since, there is no such facility in the ODL system, web-based student learning and support system should be developed and implemented using ICT to provide services at all different phases in student learning. ICT is a prime resource to overcome such limitations.

Higher education institutions across the world have been adopting ICT teaching and learning technologies in an effort to create an environment for both students and their instructors to engage in collaborative learning and gain access to information (Ifinedo, 2006). Access to information through ICT increases the information accessible to individuals to support them in trying new strategies, thinking and creativity that are reflective in practice aimed at engaging them to new innovations (Ololube, 2006b). ICTs are indispensable and have been accepted as part of the contemporary world especially in industrialized societies. In fact, cultures and societies are adjusted to meet the challenges of the knowledge age. The pervasiveness of ICT has brought about rapid changes in technology and has caused social, political, and global economic transformation (Nwachukwu, 1994; Yusuf, 2005).

The domain of distance education has not been unaffected by the penetrating influence of ICT. ICTs have impacted the quality and quantity of teaching, learning, and research in distance education. Emmanuel and Ngiye (2011:223) opine that:

Information and Communication Technology is a powerful tool for extending education opportunities to previously disadvantaged areas which include: scattered rural populations traditionally excluded from education due to cultural or social reasons such as ethnic minorities and gender. . . can result in increased learning which will be evidenced in students learning more quickly, demonstrating greater retention and being better motivated to learner.

ICT provides opportunities for distance education students and academic and non-academic staff to communicate with one another more effectively during formal and informal teaching and learning (Yusuf, 2005). For this reason, distance education programmes in Zimbabwe need to integrate ICTs into their agendas, because the quality of teaching using ICTs to gain access to information is known in virtually all countries to be a key predictor of quality student learning. Therefore, effective manpower training is crucial using ICTs, because ICTs are tools that on the one hand can facilitate human resources development, and on the other hand, help us to take full advantage of the potential of technology to enhance quality student learning via distance education (UNESCO, 2005).

\section{Barriers to the effective use of ICT by ODL students}

Open and distance teaching and learning has been dogged by a plethora of challenges that have impeded proper implementation of the programmes by institutions of higher learning. The cost of buying adequate modern computers and the appropriate software is prohibitive. Rao (2012) argues that technology is changing daily and for institutions that are dependent on ICT to operate efficiently there is need to upgrade ICT regularly. The technological features used in ODL should be designed in such a way that it is easy to upgrade as the need arises. The ICT systems should also be designed in such a way that they fulfill the demands of the student. One of the major challenges facing many landlocked middle human developmentcountries and Zimbabwe in particular is failure to operate a fast reliable internet service.Students have difficulties in accessing computers and efficient monitors (Hussain, 2007) in Gulati (2008). Most of the barriers associated with the use of ICT in ODL are succinctly captured by Tiwari and Tiwari (2010). They are of the view that:

ICT requires basic facilities such as connectivity, power, hardware (desktops, servers) and related infrastructure .... It has also been observed that wherever such facilities are available, the aspirants for taking education through distance mode are not trained to use such tools because of lack of basic knowledge of operating the computers. They do not have sufficient facilities in their educational institutions at private and secondary levels. If barriers associated with the use of ICT in ODL are not addressed, the envisaged benefits of using such technologies in ODL will remain a pipe dream. In our views, barriers to the use of ICT need to be addressed at the macro level. This can be achieved by purring in place a national ICT policy. Such a policy may go a long way towards ensuring that resources are committed into the development of ICT infrastructure as well as facilitating the acquisition of ICT equipment by individuals and education institutions at affordable prices. 


\section{Research Methodology and Design}

The study was informed by the qualitative research paradigm. A case study research design was adopted for data generation. The population consisted of ODL students who were studying at ZOU's Bulawayo and Matabeleland North Regions. Library assistants and programme coordinators in the two regions were also part of the population.The sample consisted of 30 undergraduate and postgraduate students, four library assistants and twelve programme coordinators from two of ZOU's regional centres (four per region). Purposive sampling was used to come up with the desired sample. The researcherswere the main instruments during interviewswith the library assistants and focus group discussions with programme coordinators. Data from students was collected with the aid of a questerview (an open-ended questionnaire). The anonymity of the questerview meant that participants could respond to the questions as honestly as possible, without fear of being victimized.The researchers visited the two regional libraries where they distributed questerviews to participants. Questerviews were distributed to participants and collected on the same day. During the collection of questerviews, the researchers noted any informal discussions on the phenomenon from the participants when they were handing in the completed questerviews. The researchers conducted two interviews per region with the regional library assistants. The focus of the interviews was to get an insight on the usage of the library ICT facilities. Data from preceding interviews were partially analysed before the succeeding interviews so as to cater for any gaps that would have been identified. The researchers also conducted two focus group discussions with programme coordinators.

\section{Measures to ensure trustworthiness of qualitative data}

The researchers used Guba's model for ensuring the trustworthiness of qualitative data. This was accomplished through the following steps. First, sampling decisions were carefully done. Second, data sources were triangulated by generating data from students, library assistants and programme coordinators. Third, data generation methods were triangulated through the use of questerviews (for students), interviews with library assistants and focus group discussions with programme coordinators. Fourth, interview and focus group proceedings were recorded verbatim. Fifth, transcribed data were circulated among sample members for verification. Sixth, the researchers analysed raw data and ensured intercoder and intracoder reliability among themselves.

\section{Data processing}

Transcribed interview and focus group data were taken back to the library assistants and programme coordinators who formed the study sample for verification.After verification, data were segmented, coded and categorized into themes and sub-themes.

\section{Findings And Discussion}

To what extent do ODL students make use of ICT in the preparation and writing of assignments and research?

Findings on the extent to which students make use of ICT in their assignments and research can be divided into two groups - on one side were those students who reiterated that they were using internet extensively, while on the other side were those who said they were using ICT sparingly.

\section{Extensive use of ICT}

Students pointed out that in their programmes, modules and up-to- date books covering their course outlines were limited, therefore they were forced by circumstances to make use of the internet when writing assignments, researching and preparing for examinations. Some of their sentiments on the extent to which they used ICT were:

I use internet all the time as it provides current and recent data that assists me in my research area, instead of relying on old outdated information from textbooks.

I use ICT almost every time when I am writing assignments and research projects.

Programme coordinators also corroborated the sentiments raised by the students and library assistants. Some of the programme coordinators' views are captured below:

The greater part of student assignments is done through internet research.

Most of our students rely on ICT (internet) to supplement their modules because the programme has very few hard copy textbooks in the library. 


\section{Use ICT to a lesser extent}

An appreciable number of students pointed out that they used ict facilities to a lesser extent. Some of their sentiments were:

I do not always rely on the internet, yet I sometimes access it when the need arises.

To a lesser extent because computers are always occupied.

Sentiments of less usage of ICT were also echoed by programme coordinators as one of them pointed out that: 'There is little evidence to indicate use of sources from the internet in the form of references or citations'. Yet another one said: 'Very few students access information from ICT'.

The above observations were corroborated by library assistants who pointed out that the extent of ICT usage should be looked at from two perspectives - the programme of study and the age of students. Regarding the programme of study, library assistants noted that students who used internet extensively were from the Faculty of Social Sciences, least users were from the Faculty of Arts, Education and Humanities - Department of Education. Concerning the age of users, library assistants pointed out that younger students (what we refer to as the ICT Generation) frequented computers regularly as compared to older students. The university's enrolment statistics indicated that Social Science courses were populated by younger students as compared to other programmes. The younger generation group of students was composed of post ' $\mathrm{O}$ ' and ' $\mathrm{A}$ ' Level students ranging between $18-30$ years of age. While older students were those above 30 years of age. It should also be appreciated that most of the younger generation students owned personal laptops and smart phones were they could easily access internet. Most of them could have been exposed to computers while in high school, making it easier for them to develop ICT skills. On the contrary,older students were not exposed to computers during their days in high school. Chances were that a good number of them did not own smart phones.

We also examined the Student Computer Log-in Sheet in one of the university's regional libraries to ascertain the extent to which students from different department utilized library computers. It is interesting to note that out of the manyprogrammes that were offered by the university, only students from 14 programmes used the library's computers during the month under consideration.

Frequency of Computer Usage in the Library for the Month of March by Study Programme.
\begin{tabular}{|l|c|}
\hline PROGRAMME & FREQUECNY \\
\hline Bachelor of Science Honours in Development Studies & 24 \\
\hline Bachelor of Commerce & 17 \\
\hline Bachelor of Arts in Media Studies & 15 \\
\hline Bachelor of Science Hounours in Records, Archives and Management & 13 \\
\hline Bachelor of Science Honours in Counseling & 10 \\
\hline Bachelor of Arts in English and Communication Studies & 09 \\
\hline Bachelor of Science Honours in Psychology & 05 \\
\hline Bachelor of Science Honours in Geography & 04 \\
\hline Bachelor of Science in Agriculture Management & 04 \\
\hline Bachelor of Science Honours in Special Education & 02 \\
\hline Bachelor of Science Honours in Nursing Science & 02 \\
\hline Masters in Business Administration & 02 \\
\hline Bachelor of Science Honours in Physical Education and Sports & 01 \\
\hline Masters in Peace and Leadership & 01 \\
\hline
\end{tabular}

We were aware that frequencies of computer usage could have been affected by a number of factors inter alianumber of students enrolled in the programme; due dates of assignments; year of study (assuming that students in their final semester but one will visit the library more frequently since they will be finalizing their projects); ownership of computers and smart phones by students and usage of computers in the internet cafes dotted in the city. However, notwithstanding these factors, in our view, the frequencies in the table above authentically illuminate the extent to which students used ICT in research and assignment writing.

Given the above scenario, one wonders how the rest of the students prepared for their assignments and work on their research projects. Chances were that most of the assignments from students who used the ICT facilities sparingly could be based on the study modules and the few books that were found in the library. Yet the internet has got a lot of online books, book reviews and research articles which students could benefit from. Assuming that most students do not make use of ICT facilities, the honours is on programme coordinators to encourage and indeed assist their students in the use of ICT facilities. 


\section{What challenges do students encounter in their attempt to utilize ICT?}

Students, library assistants and programme coordinators identified four major challenges limiting the extent to which students made use of ICT facilities. These challenges are presented and discussed below.

\section{Lack of ICTSkills.}

Lack of computer skills was singled out by programme coordinators, library assistants and ODL students as a very big challenge. Some of the sentiments on this challenge mentioned by students were:

I need guidance on how to research using the system because at times key result areas may not be found.

Lack of adequate knowledge on how to utilize ICTs due to lack of background education system from the early stage and income levels hinders payment of tuition fees to learn more from relevant institutions.

I am not computer literate.

During interviews with programme coordinators, the ICT skills' level of most students was highlighted. They pointed out that this was a cause for concern. Dominant contributions were:

Know how - very few of them have knowledge on using ICT for research purposes.

...lack of skills and how to research and lack of ICT practicals particularly among older students.

With some of the students being 'mature' they are not all well versed with the use of computers and ask for assistance in posing search queries and in saving what they have found in the flash drives and get appropriate material at accessing web/search engines.

The students' limitations in the use of computers were also noted by library assistants. They noted that most lack ICT skills, to the extent of not being aware that they can download onto a saving device such as a flash whatever information they may come across during browsing and later print and read at their own time. After being assisted to find information on the internet, most would want to read, write notes and move to the next article. As a result, students fail to make much headway in the one hour that each student is allocated to access the internet.

Students in all the faculties enroll for a computer module during their first year of study. It is assumed that the module prepares students for challenges they are likely to face when trying to access information through the internet, typing own assignments and submitting assignments online and communicating with their programme coordinators and tutors. However, if the concerns raised by students, library assistants and programme coordinators on ICT skills level of most students is anything to go by, the effectiveness of the computer module that students are exposed to needs interrogation. During the interrogation, the focus should be on the content of the module as well as the mode of delivery.

\section{Connectivity and the rate of downloading articles}

In our view, this challenge was highlighted by the students who were computer literate and used the ICT facilities extensively. The university depends on Internet Service Providers (ISP) to access the internet. The amount of bandwidth (megabytes/second) that the university receives depends on how much money it pays the ISP. The challenge will remain with the country's universities for a long time until such a time when universities can pull resources together and have their own optic fibre either through Botswana or Mozambique. Mafa and Mpofu (2012) highlighted that bandwidth through its impact on ICT will affect most ODL institutions'quest to adopt the third generation of service delivery.

\section{Limited access to the computers}

Most students highlighted the challenge related to limited access to ICT facilities. This comes as no surprise considering that the university's regional centre has close to a thousand students who scramble for 25 computers that are in the library. Some of the students' sentiments were:

The computers are very few for all students to have access to them.

Availability of computers (ICT) infrastructure for those based outside town.

Sometimes library computers are down and this greatly disadvantages those without personal computers. The library has very few computers.

... the number of computers in the library should be increased. Sometimes the 1 hour duration given to each student for using the computer is not enough.

Access to a computer on busy or assignment deadline days - there is heavy congestion. This is compounded by connectivity challenges.

The students' sentiments were echoed by programme coordinators and library assistants. To ameliorate the problem and ensure that as many students as possible get access to the computers, the library assistants designed a computer log-in form to control the usage of the few computers. While concurring that the one hour duration permitted each student on the computer was not adequate, library assistants were of the view that the mechanism afforded as many students as possible opportunities to have some limited access to the computers. The two regions from where data for this study were generated were in the process of setting up computer laboratories 
with a complement of 100 computers. Hopefully if up and about, the computer laboratories will go a long way towards addressing the problem of access. Perhaps, the regional computer technicians will also run some handson computers courses to equip students with basic ICT skills.

\section{The cost of acquiring ICT equipment}

Most students lamented that all other things being equal they would love to own personal ICT gadgets such as personal computers, laptops, iphones, ipads and smart phones to enable them to access internet and use the gadgets for assignments and research projects as and when they wished like. However, they bemoaned the exorbitant costs associated with acquiring these gadgets. It should be appreciated that an appreciable number of students was made up of civil servants - teachers, police officers, nurses and agriculture extension workers, whose salaries were below the country's poverty datum line. Most were having children and other dependents under their guardianship and were struggling to pay their own fees. Faced with a plethora of demanding challenges, acquiring ICT gadgets may end up appearing far below in some students' budget lists. In our view, if university students are to afford buying ICT gadgets, there is need for affirmative action. Zimbabwe can pull a leaf from the Tanzania experience where registered students from colleges and universities are allowed to buy ICT gadgets at subsidized prices.

\section{How can these challenges be addressed?}

Students cited the need to increase the number of computers, attending to computer breakdowns and improving connectivity by ISP. The major strategies mentioned by students, library assistants and programme coordinators revolved around equipping students with prerequisite skills to enable them to use ICT facilities with ease. Some of the students pointed out that:

Teaching the students on Information Literary Skills that enable them to formulate their queries and get the appropriate material at accessing web/search engines.

Someone to go around teaching those who are unable to use the gadgets all the time.

We need practical lessons in ICT from the university at an affordable fee or it can be incoperated as part of our studies.

Students' suggestions were corroborated by programme coordinators and library assistants. Some of the suggestions were that:

The university should have a generic ICT course for all students - the course should entail actual practical work as part of assignments for coursework.

The university should conduct practical computer courses for all students as part of orientation.

Every programme should have an examinable course in the practical use of computers, where students are taught and examined on how to use computers and access internet.

In our view, focusing on equipping students with relevant ICT skills is a brilliant idea since students will be able to visit internet cafes to access the internet instead of waiting their turn to use the few university computers. Chances are that if students visit internet cafes deficient in computer skills, employees in the cafes may not have the patient to frequently assist the students. Also as noted earlier, the call for hands-on computer training of students, justifies the need to revisit the computer course that is offered to all first year students.

\section{Conclusion And Recommendations}

The findings show that the extent to which ODL students made use of ICT in their assignments and conducting research depended on age of students and programmes of study. Notwithstanding these findings, it can be concluded that very few students made use of ICT due to problems linked to ICT skills' levels of most students and access to the few university computers. We therefore recommend that: First, ODL students need hands-on training in using ICT facilities. Second, the university should increase the number of computers in its regional libraries and computer laboratories. Third, the present computer module being offered to all first year students needs to be revisited to establish its effectiveness in equipping students with computer skills. Fourth, the government of Zimbabwe should consider coming up with a policy where registered tertiary students could buy laptops at subsidized prices.

\section{References}

[1]. Akpan, C. P. (2008). Enhancing Quality in Open and Distance Education through Effective Utilization of Information and Communication Technology (ICT) in Nigeria. A paper presented at the $2^{\text {nd }}$ African Council for Distance Education (ACDE) Conference and General Assembly 8-11 July, 2008, Lagos, Nigeria.

[2]. Emmanuel, S. C. and Ngiye, M. G. (2011). Online Teaching of Languages: A case study of Moi University, Kenya. In Journal of Language, Technology and Entrepreneurship in Africa, 3(1), 223-244.

[3]. Gulati, S. (2008). Technology-Enhanced Learning in Developing Nations: A Review of Research in Open Learning, 9(1), 1-16.

[4]. Ifinedo, P. (2006). Acceptance and Continuation Intention of Web-Based Learning Technologies (WLT) among University Students in a Baltic Country. In The Journal of Information Systems in Developing Countries, 23(6), 1-20. 
[5]. Mafa, O. and Mpofu, J. (2012). Impact of Funding on the Adoption of Third Generation Delivery in Open Distance Learning in Zimbabwe. A paper presented at the $47^{\text {th }}$ Distance Education Association of Southern Africa (DEASA), Swakopmund, Namibia.

[6]. Murali, A. M. R. (2008). ICT in Open Distance Learning: Issues and Challenges. http://wikieducator.org/images/4/49/A._Murali_M_Rao.pdf (10th March, 2013).

[7]. Nwachukwu, M. A. (1994). Development of Information Technology in Nigeria. In Drew, E. P. and Foster, F. G. (eds.), Information Technology in Selected Countries. Tokyo: The United Nations University.

[8]. Ololube, N. P. (2006b). Appraising the Relationship Between ICT Usage and Integration and the Standard of Teacher Education Programs in a Developing Economy. In International Journal of Education and Development using Information and Communication Technology, 2(3), 70-85.

[9]. Rouse, M. (2005). ICT ) Information and Communication Technology, www.maximise.ICT.co

[10]. Tiwari, I. and Tiwari, T. G. (2010). Impact of Information Communication Technology on Open Learning in India. In IJCSNS International Journal of Computer Science and Network Security, 10(11), 80-85.

[11]. UNESCO (2005). United Nations Decade of Education for Sustainable Development 2005-2014. http://portal.unesco.org/education/en/ev.php-URL_ID=27234\&URL_DO=DO_TOPIC\&URL_SECTION=201.html.

[12]. Yusuf, M. O. (2006). Problems and Prospects of Open and Distance Education in Nigeria. Turkish Online Journal of Distance Education - TOJDE, 7(1), 22-29. 